\title{
Research on the influence of government support on the innovation performance of manufacturing enterprises from a perspective of open innovation
}

\author{
Zhangsheng Jiang ${ }^{1, a}$, Feifei Wang ${ }^{2, b, *}$ \\ ${ }^{1}$ School of Business Administration, Zhejiang Gongshang University, Xuezheng Street, Hangzhou, China \\ ${ }^{2}$ School of Business Administration, Zhejiang Gongshang University, Xuezheng Street, Hangzhou, China \\ ajjy0567@gmail.com, ${ }^{\text {b } 847540181 @ q q . c o m ~}$
}

Keywords: Government support, Open innovation, Innovation performanc, Listed companies

\begin{abstract}
This study takes more than 400 listed companies in the manufacturing industry as the research object, and deeply analysis the relationship among government support, open innovation and innovation performance and its impact mechanism. The study draws the following conclusions: (1) Government support has a significant impact on innovation performance. Which government subsidies have a negative impact on innovation performance, tax incentives have a positive impact on performance; (2)The breadth and depth of open innovation have a significant positive impact on innovation performance; (3) Tax incentives have a significant positive impact on open innovation, government subsidies have no significant impact on open innovation; (4) The effect of open innovation on the relationship between government subsidies and innovation performance is not significant. Open innovation plays a mediating role in the relationship between tax incentives and innovation performance.
\end{abstract}

\section{Introduction}

In the context of the era of knowledge economy, the limitations of the traditional closed innovation model have been expanding, and the model of open innovation has gradually become an inevitable trend of the development of the times. With the advancement of the open innovation model, local governments are also playing an increasingly important role in enterprise innovation activities. For example, the government formulates technical standards for products, regulates the technology trading market, and promotes the advancement of open innovation models through various means such as direct subsidies, provision of R\&D projects, and tax incentives. Faced with the complex and changeable economic situation, especially under the background of "Double Innovation" and "Made in China 2025" strategy, the particularity of government support policy has a particularly important impact on the innovation performance of China's manufacturing industry.

In the existing research literature, most scholars believe that government support as a tangible hand is conducive to resource allocation, can promote enterprise technology innovation, and thus improving enterprise innovation performance (Zeng et al, 2014; Wang, 2010; Zheng and Liu, 2008; Bronzini et al, 2016; Czarnitzki et al, 2011). Regarding government support, whether it is examined from the whole perspective or according to different support methods (such as government subsidies and tax incentives), the view that government support can promote enterprise innovation performance has been supported by a large number of empirical evidence. In addition, there are some literatures show that government-related support policies (tax or subsidy, etc.) have a positive role in promoting open innovation of enterprises. All governments try to influence the demand of open innovation through these policies and stimulate the necessary characteristics of open innovation cooperation (Groeneveld, 2008; Vanhaverbeke et al, 2008; Ren, 2017). There are also literatures, based on various perspectives (knowledge absorption and integration or market orientation, etc.), confirmed that open innovation can promote the improvement of innovation performance (Zhang et al, 2015; Guo, 2016; Cheng et al, 2010; Yang et al, 2015; Lichtenthaler et al, 2010; Zheng et al, 2017). However, there are very little literatures have studied the relationship 
among government support, open innovation and innovation performance. So, what kind of mechanism of action exists among them? Does open innovation plays a mediating role between government support and innovation performance? Therefore, this study attempts to uncover the "black box" between the three of them from the perspective of institutional theory and open innovation theory.

The theoretical value of this paper is to examine the influence mechanism of government support on enterprise innovation performance from the perspective of open innovation, which not only enriches the theory of institutional theory and open innovation theory, but also expands the research of enterprise technology innovation path. At the same time, the new concept brought about by open innovation provides the direction for the government to formulate policies, which has certain practical guiding significance. The structure of this paper is as follows: the second part is the theoretical analysis and empirical analysis; the third part is the empirical analysis; the fourth part is the conclusion and enlightenment of this paper.

\section{Research Design}

\subsection{Research Hypothesis}

\subsubsection{Government Support and Innovation Performance}

In order to make up for market failures, achieve the improvement of innovation efficiency and the optimal allocation of market resources, governments of all countries generally improve the efficiency of enterprises in innovation activities through government subsidies, tax incentives and other means. Tax incentives and government subsidies, as the tools for the country's macroeconomic regulation and control, have provided support for the development of China's manufacturing enterprises while regulating the healthy and orderly development of the market.

Because there are two risks of "price spillover" and "knowledge spillover" in technological innovation activities, government subsidies as external funds can not only increase the innovation input of enterprises, but also effectively compensate the positive externalities of R\&D activities of enterprises and promote the spillover of R\&D results (Luo and Xiang, 2001). From this point of view, government subsidies can reduce the risk of enterprise $R \& D$, which is conducive to the development of enterprise innovation and $R \& D$ activities, thus improving the innovation performance of enterprises. Bérubé and Mohne (2009) used Canadian microdata to measure government subsidies and demonstrate the effectiveness of innovation. Zhao et al. (2017) found a significant positive correlation between enterprise R\&D subsidies and innovation performance.

The government's tax policies such as pre-tax deduction, accelerated depreciation, and income tax concessions for enterprise $R \& D$ can not only reduce the cost of $R \& D$, but also encourage enterprises to invest more capital in R\&D. Huang et al. (2015) used the industrial data of the manufacturing industry from 2011 to 2013 to measure government support with the tax incentives for R\&D expenses minus tax reduction and exemption policies. The results showed that external tax incentives promoted enterprises to invest in $\mathrm{R} \& \mathrm{D}$ activities and technological innovation. Li et al. (2016) found in the latest five years of big data research of listed companies that tax incentives will positively affect $R \& D$ output, which can reduce the risk of $R \& D$ investment by transforming into internal resources, thus promoting the development of $R \& D$ activities. In addition, most studies showed that government tax incentives play a positive role in promoting R\&D innovation in SMEs (Gale et al, 2013; Intarakumnerd et al, 2016; Bergner et al, 2017). Therefore, we propose:

Hypothesis 1: Government support has a significant positive impact on innovation performance.

Hypothesis 1a: Government subsidies have a significant positive impact on innovation performance.

Hypothesis 1b: Tax incentives have a significant positive impact on innovation performance.

\subsubsection{Government support and open innovation}

Based on the view of Laursen and Salter, this study examines the relationship between open innovation and government support from the perspective of the breadth and depth of open 
innovation.

The breadth of open innovation refers to the amount of external resources that enterprises cooperate with in the practice of open innovation. The depth of open innovation is the closeness of innovation cooperation with external resources in the practice of open innovation (Guo, 2016). Therefore, an important embodiment of open innovation lies in technological innovation cooperation between enterprises and external network entities. Most studies showed that the basis of open innovation is to strengthen innovation partnerships with suppliers, government research institutions and competitors (Hippel, 1986; Huizingh, 2011). The government support can stimulate internal $R \& D$ of enterprises and promote internal and external collaboration. It can be seen that relevant government policies can create a good macro environment for enterprises' open innovation (Tang and Meng, 2015). Some scholars found that the government, as an advocate of open innovation and policy makers, can guide and promote technological innovation cooperation of enterprises, thus accelerating scientific and technological innovation of enterprises (Yu, 2012; Ni, 2015). As the two major policy tools, government subsidies and tax incentives directly or indirectly give enterprises certain financial support, which is conducive to attracting other network entities to join, and thus promoting open innovation of enterprises. Based on this, we propose:

Hypothesis 2: Government support has a significant positive impact on open innovation.

Hypothesis 2a: Government subsidies have a significant positive impact on the breadth of open innovation.

Hypothesis 2b: Government subsidies have a significant positive impact on the depth of open innovation.

Hypothesis 2c: Tax incentives have a significant positive impact on open innovation breadth.

Hypothesis 2d: Tax incentives have a significant positive impact on the depth of open innovation.

\subsubsection{Open innovation and innovation performance}

At present, most researches on open innovation are based on the innovation network theory. Enterprises constantly communicate through the innovation network, which is conducive to promoting the integration of external resources and improving innovation performance (Zhao and Zhang, 2016). Uzzi (1997) and Phelps et al. (2009) pointed out in their research that the strong relationship between network subjects can constitute overlapping networks and promote the sharing of information and knowledge among network subjects, which can better promote the formation of a series of open innovation achievements of. According to Beers and Zand (2014), the diversity of the cooperative subjects strengthens the degree of trust between cooperative subjects, weakens the obstacle of searching local knowledge, and then improves the innovation performance of enterprises. At the same time, the complementary and interdisciplinary knowledge acquired by enterprises is beneficial for enterprises to absorb more tacit knowledge and thus promote enterprise innovation. It can be seen that the openness of innovation will bring more new knowledge to enterprises in both the breadth and depth of openness and promote the improvement of innovation performance. Li et al. (2018), based on the research of Chinese automobile enterprises, found that enterprises can achieve the integration with internal knowledge through the absorption of external information resources, improve their own cognitive level, and then influence the innovation performance. In addition, He and Chen (2010) and Greco (2016) all believed that the breadth and depth of network subject relationship will directly affect the innovation performance of enterprises in the process of open innovation. We therefore propose:

Hypothesis 3: Open innovation has a significant positive impact on innovation performance.

Hypothesis 3a: The breadth of open innovation has a significant positive impact on innovation performance.

Hypothesis 3b: The depth of open innovation has a significant positive impact on innovation performance.

\subsubsection{Government Support, Open Innovation and Innovation Performance}

Most studies suggest that government support is good for open innovation of enterprises. By 
formulating relevant supporting policies and giving proper guidance to enterprises, government departments can strengthen cooperation among the innovation network subjects, so that they can effectively use external innovation resources through open innovation. In addition, , the research results on the learning mechanism of open innovation also indicate that the enhancement of innovation openness will promote the improvement of innovation performance. Although the open innovation model may increase the transaction cost and information searching cost, and may face the risk of leakage of internal technical knowledge, open innovation can greatly reduce the uncertainty of technology and market, so that the enterprise innovation can be successful. Therefore, government support, as an incentive method in the institutional environment, directly affects the breadth and depth of open innovation by providing subsidies or tax incentives, enabling enterprises to obtain external diversified knowledge resources and thereby promoting the improvement of innovation performance. So we propose:

Hypothesis 4: Open innovation plays a mediating role in the relationship between government support and innovation performance.

Hypothesis 4a: The open innovation breadth plays a mediating role in the relationship between government subsidies and innovation performance.

Hypothesis 4b: The extent of open innovation plays a mediating role in the relationship between tax incentives and innovation performance.

Hypothesis 4c: The depth of open innovation plays a mediating role between government subsidies and innovation performance.

Hypothesis 4d: The depth of open innovation plays a mediating role between tax incentives and innovation performance.

\subsection{Variables}

We selected A-share Manufacturing Listed Companies in Shanghai and Shenzhen Stock Exchanges from 2011 to 2015 as the research object. By using the data resources of Tonghuashun database and Baiteng Patent Retrieval System, 436 innovative enterprises were selected after eliminating the companies whose stocks were identified as "ST stocks" by the SFC and the companies whose indicators were missing.

\subsubsection{Explained variable}

Innovation performance is defined as the level of innovation output. Its measure standard does not have the unified opinion in academia. This is due to the complexity and diversity of the technological innovation process and output of enterprises. Under the open innovation mode, the measurement of enterprise performance cannot only look at the financial performance on the surface of the enterprise, but should pay more attention to the difference of enterprise innovation performance. Since the number of patents in an enterprise reflects a breakthrough in the $R \& D$ technology of the enterprise and is the embodiment of technological innovation, the number of patent applications will be chosen to measure the variable of innovation performance. At the same time, considering the lag of patent applications, the average number of subjects in the previous year, the next year and this year is selected as the number of patent applications.

\subsubsection{Explanatory variables}

(1) Government support

Government support in this study mainly include government subsidies and tax incentives.

The measurement of government subsidies is mainly based on the capital flow of government, considering the availability of data, the non-operating income in the annual report of the enterprise is adopted as the indicator of government subsidies.

In addition, this study uses the B Index proposed and gradually improved by Warda (1996) to measure the effect of government tax incentives policies, and take the government's tax incentive amount on enterprise's technological innovation activities as an indicator to examine government tax incentives. It reflects the after-tax cost of per unit R\&D expenditure, which is the intensity of the implementation of $R \& D$ tax incentives for Chinese enterprises. The tax incentives of the $B$ 
Index are relative to the enterprise income tax. The tax incentives of the B index are relative to the enterprise income tax, not considering other taxes such as turnover tax, personal income tax, etc., and assuming that the enterprise can obtain sufficient taxable income in the following year, that is, the enterprise is assumed to enjoy the tax incentives policy.The calculation formula of B index: $B=(1-v t)(1-t)$. Where $t$ is the enterprise income tax rate, when the enterprise enjoys the pre-tax deduction, the after-tax cost of each unit of $\mathrm{R} \& \mathrm{D}$ investment is $1-v t$, of which $v$ is the pre-tax deduction rate. This paper refers to the study of Dai and Liu (2008), setting the enterprise 's weighted pre-tax deduction rate to $140 \%$.

(2) Open innovation

Open innovation includes the breadth and depth of open innovation.

The measurement of the breadth of open innovation is mainly based on the research of Laursen and Salter (2006), which is measured by the total number of cooperation with external innovation elements (including suppliers, customers, competitive enterprises, etc.) in the innovation process.

For the measurement of the depth of open innovation, scholars made different suggestion. Katila and Ahuja (2002) measured the breadth of open innovation by the proportion of repeatedly cited patents to the total number of patents cited. Laursen and Salter (2006) measured the depth of open innovation by the frequency of connection with which companies connect with innovation elements in the innovation process. He et al. (2010) used the frequency of cooperation between enterprises and other subjects in the network to measure the depth of open innovation. Chen and Chen (2008) adopted the Likert seven-level scale to measure the frequency of information exchange between enterprises and external innovation elements in innovation activities to measure the depth of open innovation. This study believes that the data obtained in the form of questionnaire of the seven-level scale lacks objectivity. Considering the availability of the data, we will use the number of joint patent applications to express the depth of open innovation.

\subsubsection{Control Variables}

According to the existing studies, we select enterprise size, enterprise age, asset-liability ratio and the proportion of R\&D cost in operating income as control variables. Furthermore, we measure the scale of the enterprise by the number of employees, and measure the age of the enterprise by the years of its establishment.

\subsection{Descriptive Statistics and Correlation Test of Main Variables}

Descriptive statistics and correlation tests are performed for the main variables in this study. The results show that the correlation coefficient between each variable is positive. And the $\mathrm{P}$ value is less than 0.01 , that is, they are significantly correlated at the level of 0.01 . Overall, the correlation is statistically significant.

\section{Empirical Analysis}

This study is to examine the correlation between government support and enterprise innovation performance and the mediating role of open innovation in the impact of government support on innovation performance. Firstly, according to Aiken and West (1991), the variables such as government subsidies, tax incentives, the breadth and depth of open innovation were standardized by SPSS before the regression analysis. Secondly, the three-step median regression method is used to test the mediating effect of open innovation. In addition, this study uses the commonly used redundancy test and Hausmann test to determine which panel data model is selected. The results showed that the $\mathrm{P}$ values of the model test were all equal to $0(\mathrm{P}<0.05)$, so all models adopted the fixed effect model. On this basis, a co-integration test was performed on the model, and the results showed that the residual term is stable, indicating that the model has a long-term equilibrium relationship.

(1) Regression analysis of government subsidies, open innovation, and innovation performance

Table 1 shows the empirical results of the relationship among government subsidies, open innovation and enterprise innovation performance. Model 2 shows that government subsidies have a 
significant negative impact on innovation performance (regression coefficient is $-0.061, \mathrm{p}<0.01$ ), so Hypothesis 1a is not supported. Model 3 and Model 5 test the impact of government subsidies on the breadth and depth of open innovation. The results show that the regression coefficients are 0.009 and 0.0118 respectively, but they are not statistically significant, neither Hypothesis 2a nor Hypothesis 2b is supported. Models 2, 3, and 4 examine the mediating effect of the breadth of open innovation. The results show that the relationship between government subsidies and the breadth of open innovation is not significant (regression coefficient is 0.009), while the breadth of open innovation has a significant positive effect on innovation performance (regression coefficient is $0.375, \mathrm{p}<0.01$ ), so Sobel test is needed. The calculation shows that $\mathrm{Z}=0.009$ fails to pass the significance test, so the mediating effect of the breadth of open innovation is not significant, so Hypothesis 4a is not supported. Models 2, 5, and 6 examine the mediating effect of the depth of open innovation. The results show that the relationship between government subsidies and open innovation is not significant (regression coefficient is 0.0118 ), and the depth of open innovation has a significant positive effect on innovation performance (regression coefficient is $0.430, \mathrm{p}<0.01$ ), so Sobel test is needed. The calculation shows that $\mathrm{Z}=0.507$ fails to pass the significance test, so the mediating effect of the depth of open innovation is not significant, so Hypothesis 4c is not supported.

Table 1 Regression analysis of government subsidies, open innovation, and innovation performance

\begin{tabular}{|c|c|c|c|c|c|c|}
\hline \multirow[t]{2}{*}{ Explained Variables } & $\begin{array}{l}\text { Innovation } \\
\text { performance }\end{array}$ & $\begin{array}{l}\text { Innovation } \\
\text { performance }\end{array}$ & $\begin{array}{l}\text { The breadth } \\
\text { of open } \\
\text { innovation }\end{array}$ & $\begin{array}{l}\text { Innovation } \\
\text { performance }\end{array}$ & $\begin{array}{l}\text { The depth } \\
\text { of open } \\
\text { innovation }\end{array}$ & $\begin{array}{l}\text { Innovation } \\
\text { performance }\end{array}$ \\
\hline & Model 1 & Model 2 & Model 3 & Model 4 & Model 5 & Model 6 \\
\hline \multicolumn{7}{|l|}{ Control Variables } \\
\hline $\begin{array}{l}\text { the proportion of } R \& D \\
\text { cost in operating } \\
\text { income }\end{array}$ & -0.031 & -0.030 & -0.013 & -0.025 & -0.006 & -0.027 \\
\hline Enterprise Size & $0.1^{* * *}$ & $0.122 * * *$ & $0.140 * * *$ & $0.070^{* *}$ & $0.129 * * *$ & $0.067^{* *}$ \\
\hline Asset-liability Ratio & 0.010 & -0.011 & -0.051 & 0.008 & $-0.054 *$ & 0.012 \\
\hline Enterprise age & $0.106^{* * *}$ & $0.120 * * *$ & $0.174 * * *$ & $0.055^{* *}$ & $0.144 * * *$ & $0.058^{*}$ \\
\hline \multicolumn{7}{|l|}{ Explanatory Variables } \\
\hline Government support & & $-0.061^{* * *}$ & 0.009 & $-0.064 * * *$ & 0.0118 & $-0.066^{* * *}$ \\
\hline $\begin{array}{l}\text { The breadth of open } \\
\text { innovation }\end{array}$ & & & & $0.375^{* * *}$ & & \\
\hline $\begin{array}{l}\text { The depth of open } \\
\text { innovation }\end{array}$ & & & & & & $0.430 * * *$ \\
\hline $\mathrm{R}^{2}$ & 0.883 & 0.884 & 0.793 & 0.913 & 0.810 & 0.918 \\
\hline
\end{tabular}

$* * * \mathrm{p}<0.01, * * \mathrm{p}<0.05, * \mathrm{p}<0.1$

(2) Regression analysis of tax incentives, open innovation, and innovation performance

Table 2 shows the empirical results of the relationship among tax incentives, open innovation and enterprise innovation performance. Model 7 shows that the tax incentives have a significant positive impact on innovation performance (regression coefficient is $0.381, \mathrm{p}<0.01$ ), consistent with Hypothesis 1b. Model 8 and Model 10 test the impact of tax incentives on the breadth and depth of open innovation. The results show that the regression coefficients are $0.814(\mathrm{p}<0.01)$ and 0.884 $(\mathrm{p}<0.01)$ respectively, and they are statistically significant, consistent with Hypothesis 2c and 2d. Models 7, 8 and 9 examine the mediating effect of the breadth of open innovation. The results show that tax incentives have a significant positive effect on the breadth of open innovation (regression coefficient is $0.814, \mathrm{p}<0.01$ ), and the breadth of open innovation has a significant positive effect on innovation performance (regression coefficient is $0.354, \mathrm{p}<0.01$ ), and the direct effect of tax incentives on innovation performance is significant (regression coefficient is $0.092, p<0.01$ ), so the 
breadth of open innovation plays a partial mediating role, consistent with Hypothesis 4b.Models 7, 10, and 11 examine the mediating effect of the depth of open innovation. The results show that tax incentives have a significant positive effect on the depth of open innovation (regression coefficient is $0.884, \mathrm{p}<0.01$ ), and the depth of open innovation has a significant positive effect on innovation performance (regression coefficient is $0.429, \mathrm{p}<0.01$ ), but the direct effect of tax incentives on innovation performance is not significant (regression coefficient is 0.001), indicating that the depth of open innovation plays a full mediating role, consistent with Hypothesis 4d.

Table 2 Regression analysis of tax incentives, open innovation, and innovation performance

\begin{tabular}{|c|c|c|c|c|c|}
\hline Explained Variables & $\begin{array}{c}\text { Innovation } \\
\text { performance } \\
\text { Model } 7\end{array}$ & $\begin{array}{l}\text { The breadth of } \\
\text { open } \\
\text { innovation } \\
\text { Model } 8\end{array}$ & $\begin{array}{c}\text { Innovation } \\
\text { performance } \\
\text { Model } 9\end{array}$ & $\begin{array}{c}\text { The depth of } \\
\text { open innovation } \\
\text { Model } 10\end{array}$ & $\begin{array}{c}\text { Innovation } \\
\text { performance } \\
\text { Model } 11\end{array}$ \\
\hline $\begin{array}{l}\text { Control Variables } \\
\text { the proportion of } \\
\text { R\&D cost in } \\
\text { operating income }\end{array}$ & -0.030 & -0.011 & -0.027 & -0.003 & -0.029 \\
\hline Enterprise Size & $0.073 * * *$ & $0.083^{* *}$ & $0.043 *$ & $0.069 *$ & $0.043 *$ \\
\hline $\begin{array}{l}\text { Asset-liability Ratio } \\
\text { Enterprise age }\end{array}$ & $\begin{array}{c}-0.017 \\
0.068 * * *\end{array}$ & $\begin{array}{c}-0.067^{*} \\
0.095^{*}\end{array}$ & $\begin{array}{l}0.007 \\
0.034\end{array}$ & $\begin{array}{c}-0.070 * * \\
0.059 *\end{array}$ & $\begin{array}{l}0.013 \\
0.043\end{array}$ \\
\hline Explanatory Variables & & & & & \\
\hline $\begin{array}{l}\text { Tax incentives } \\
\text { The breadth of open } \\
\text { innovation }\end{array}$ & $0.381 * * *$ & $0.814 * * *$ & $\begin{array}{c}0.092 * * \\
0.354 * * *\end{array}$ & $0.884 * * *$ & 0.001 \\
\hline $\begin{array}{c}\text { The depth of open } \\
\text { innovation } \\
\mathrm{R}^{2}\end{array}$ & 0.891 & 0.830 & 0.9 & 0.8 & $\begin{array}{c}0.429 * * * \\
0.918\end{array}$ \\
\hline$* * * \mathrm{p}<0.01, * * \mathrm{p}<0$ & $\mathrm{p}<0.1$ & & & U.0J0 & 0.910 \\
\hline
\end{tabular}

Combining Table 1 and Table 2, the breadth and depth of open innovation have a significant positive effect on innovation performance, which is consistent with Hypothesis 3a and 3b.

\section{Conclusions and Implications}

This paper uses the panel data of 436 listed companies as a research sample, and studies the relationship among government support, open innovation and innovation performance based on the combination of theory and demonstration, and draws several research conclusions: (1) Government subsidies have a significant negative impact on innovation performance, while tax incentives have a significant positive impact on innovation performance. One possible reason is that government subsidies are ex ante subsidies, which have good short-term effects but not obvious long-term ones. Second, the behavior of government subsidies will crowd out the enterprises' own R\&D expenditure to a certain extent and produce substitution effect. However, tax incentives not only reduce research and development costs, but also can encourage enterprise to invest more funds for innovation activities. (2) Government subsidies have no significant positive impact on open innovation, while tax incentives have a significant positive impact on open innovation. This indicates that tax incentives can encourage enterprises to strengthen cooperation with external innovation network entities. (3) The breadth and depth of open innovation have significant positive effects on innovation performance. This shows that the higher the degree of openness of enterprise innovation, the better the enterprise innovation performance. (4) The mediating effect of open innovation on the relationship between government subsidies and innovation performance is not significant, but plays a mediating role in the relationship between tax incentives and innovation performance. This illustrates that tax incentives can better improve innovation performance through an open innovation process.

The above research conclusions have certain implications and guiding significance for improving the innovation performance of Chinese manufacturing enterprises: (1) The government can change 
the one-time government subsidy to be paid in advance, during and after. It can also encourage scientific research institutions to work closely with enterprises through indirect subsidies to promote their research and development. (2) The government should increase tax incentives for enterprise innovation activities. Through the establishment and improvement of the performance evaluation mechanism of tax incentive policies, the degree of accuracy and incentive effect could be improved. Meanwhile, all kinds of bonuses and allowances obtained by researchers for research and development activities could be exempted from personal income tax, and $R \& D$ personnel could be encouraged to actively innovate. (3) The enterprise should cultivate its own dynamic capabilities, attach importance to and strengthen the innovative cooperative relationship with enterprises, suppliers and governments in the innovation network, improve the innovation openness of the enterprise, make up for the deficiency of the internal innovation resources of the enterprise, and then improve the innovation performance. (4) The government should mobilize the initiative of the innovation network entities with preferential tax policies, and create an open innovation and development atmosphere to improve the innovation performance of enterprises.

\section{Acknowledgment}

The research is supported by the national social science foundation: ( grant number: 17BGL019 ): Research on the relationship among government innovation support, open innovation model and innovation performance for manufacturing enterprises.

\section{References}

[1] Czarnitzki D, Hanel P, Rosa J M. Evaluating the Impact of R\&D Tax Credits on Innovation: A Microeconometric Study on Canadian Firms[J]. Research Policy, 2011, 40(2):217-229.

[2] Groeneveld R. The Government as Actor in Open Innovation How the Dutch government Stimulates Open Innovation[J]. 2008.

[3] Lichtenthaler U, Ernst H. Opening up the Innovation Process: the Role of Technology Aggressiveness[J]. R \& D Management, 2010, 39(1):38-54.

[4] Guo Wei. An Empirical Study on the Impact of Innovation Openness on Enterprise Innovation Performance[J]. Research Management, 2016, 37(10): 43-50.

[5] Zhao Yuanjun, Xu Guiping, Liu Wei, et al. Research on the Innovation Performance of Chinese Enterprises from the Perspective of Government Support[J]. Research Management, 2017(s1): 412-418.

[6] Intarakumnerd P, Goto A. Technology and Innovation Policies for Small and Medium-Sized Enterprises in East Asia[J]. Adbi Working Papers, 2016.

[7] Bergner S, Bräutigam R, Evers $M$, et al. The Use of SME Tax Incentives in the European Union[J]. Zew Discussion Papers, 2017.

[8] Laursen K, Salter A. Open for Innovation: the Role of Openness in Explaining Innovation Performance among U.K. Manufacturing Firms[J]. Strategic Management Journal, 2006, 27(2):131-150.

[9] Ni Ziyin, Zhang Yiming. Research on Government Behavior and Policy Environment Affecting Open Innovation[J]. East China Economic Management, 2015(1):148-152.

[10] Van Beers C, Zand F. R\&D Cooperation, Partner Diversity, and Innovation Performance:an Empirical Analysis[J]. Journal of Product Innovation Management, 2014, 31(2):292 -312.

[11] Li Xianjun, Zhong Ling, Wang Jinglun, et al. The Impact of Open Innovation and Absorptive Capability on Innovation Performance: Based on the Empirical Study of Chinese Automobile Enterprises [J]. Research Management, 2018, V39(1): 45-52.

[12] Liu Guangqiang. Analysis of the Incentive Effect of Tax Preferential and Financial Subsidy Policy_-An Empirical Study Based on the Perspective of Information Asymmetry Theory[J]. Management World, 2016(10): 62-71. 